\title{
Engrailed Is Required in Maturing Serotonin Neurons to Regulate the Cytoarchitecture and Survival of the Dorsal Raphe Nucleus
}

\author{
Stephanie R. Fox and Evan S. Deneris \\ Department of Neurosciences, School of Medicine, Case Western Reserve University, Cleveland, Ohio 44106
}

\begin{abstract}
Analysis of constitutive Engrailed (En) null mice previously implicated the two En homeobox paralogs in the development of serotonin (5-HT) neurons. An unresolved question is whether En plays intrinsic roles in these neurons. Here, we show that En1 and En2 are expressed in maturing 5-HT neurons that will form the dorsal raphe nucleus (DRN) and part of the median raphe nucleus. Although En1 expression in 5-HT neurons persists postnatally, En2 expression is extinguished by embryonic day 17.5. To investigate intrinsic serotonergic functions for $E n 1 / 2$, we generated compound conditional $E n$ mutants with floxed alleles and a cre recombinase line that becomes active in postmitotic fetal 5-HT neurons. We present evidence in support of a requirement for En1/2 in the maturation of DRN cytoarchitecture. The disruption of DRN cytoarchitecture appears to result from a defect in secondary migration of serotonergic cell bodies toward the midline rather than disruption of their primary ventral migration away from the ventricular zone. Furthermore, En 1/2 are required for perinatal maintenance of serotonergic identity and postnatal forebrain 5-HT levels. Increased numbers of caspase-3-expressing cells and loss of significant numbers of 5-HT neuron cell bodies, indicative of apoptosis, occurred after loss of serotonergic identity. Analysis of an allelic series of conditional mutants showed that $E n 1$ is the predominant functional $E n$ paralog in maturing 5-HT neurons, although a small contribution from $E n 2$ was reproducibly detected. Together, our findings reveal complex intrinsic functions for $E n$ in maturing 5-HT neurons, hence necessitating a reinterpretation of their roles in 5-HT system development.
\end{abstract}

\section{Introduction}

The development of serotonin (5-HT) neurons comprises a brief period of neurogenesis followed by a prolonged maturation period in which newly born postmitotic 5-HT neurons are maintained and integrated with CNS circuitry. During serotonergic neurogenesis, a transcriptional network (Deneris and Wyler, 2012) comprising Ascl1, Nkx2.2, and Foxa2 specifies serotonergic progenitors (Briscoe et al., 1999; Pattyn et al., 2004; Jacob et al., 2007) and induces expression of Insm-1, Gata-2, and Gata-3. Insm- 1 and Gata- 2 then activate expression of Lmx1b and Pet-1 in postmitotic precursors (Craven et al., 2004; Jacob et al., 2009), which together with Gata-3 induce transcription of a gene battery encoding 5-HT synthesis, vesicular transport, reuptake, and metabolism (Ding et al., 2003; Hendricks et al., 2003; Pattyn et al., 2004). 5-HT neuron maturation begins immediately after the

\footnotetext{
Received Nov. 22, 2011; revised March 22, 2012; accepted April 13, 2012

Author contributions: S.R.F. and E.S.D. designed research; S.R.F. performed research; S.R.F. and E.S.D. analyzed data; S.R.F. and E.S.D. wrote the paper.

This work was supported by National Institutes of Health Grant R01 MH062723 (E.S.D.) and Predoctoral Training Grants 5T32HD007104 and 5T32NS067431 (S.R.F.) and National Institute of Mental Health Silvio 0. Conte Center Grant P50 MH078028 (Vanderbilt University, R. Blakely, Center Director) (E.S.D.). We thank Alexandra Joyner for giving us the floxed engrailed 1 and 2 mice and the pan-engrailed antiserum. We thank Jerry Silver for valuable discussions and helpful comments. We thank Kathy Lobur for genotyping assistance. We thank Jon Rawlings for writing the program used for cell counting and Steve Wyler, Meredith Whitney, and Clay Spencer for comments on this manuscript.

Correspondence should be addressed to Evan Deneris, Case Western Reserve University, School of Medicine, Department of Neuroscience, 2109 Adelbert Road, Cleveland, 0H 44106-4975. E-mail: esd@case.edu.

DOI:10.1523/JNEUROSCI.5829-11.2012

Copyright $\odot 2012$ the authors $\quad 0270-6474 / 12 / 327832-11 \$ 15.00 / 0$
}

cessation of serotonergic neurogenesis and continues through the third postnatal week (Lidov and Molliver, 1982a,b). During this period, 5-HT neurons follow disparate migratory routes to form the various raphe nuclei in the midbrain, pons, and medulla, extend axonal projections to form the ascending and descending 5-HT subsystems, and finally integrate with target circuitry by making synaptic connections. Some recent evidence indicates that, after serotonergic neurogenesis, Pet-1 and Lmx1b continue to regulate key steps in 5-HT neuron maturation and maintenance, including the induction of the Htr1A and $H \operatorname{tr} 1 B$ autoreceptor genes (Liu et al., 2010) and postnatal survival of 5-HT neurons (Zhao et al., 2006). However, in contrast to the growing understanding of the transcriptional network governing serotonergic neurogenesis, the regulatory factors required for maturation and maintenance of 5-HT neurons remain poorly understood (Deneris, 2011).

Engrailed (En) homeobox paralogs, En1 and En2, play critical roles in limb development (Loomis et al., 1996), mid-hindbrain patterning (Liu and Joyner, 2001), cerebellar development (Millen et al., 1995; Kuemerle et al., 1997; Sgaier et al., 2007; Sillitoe et al., 2008, 2010), and the maintenance and survival of midbrain dopamine (DA) neurons (Simon et al., 2001; Albéri et al., 2004). En genes have also been implicated in Drosophila and mouse 5-HT neuron development (Lundell et al., 1996; Simon et al., 2005). In En1/2 constitutive null mice, nearly all 5-HT neurons of the developing dorsal raphe nucleus (DRN) were missing at embryonic day 12 while 5-HT neurons in the median raphe nucleus $(\mathrm{MRN})$ and posterior hindbrain were unaffected (Simon et al., 
2005). Immunohistochemical studies, however, failed to detect En expression in 5-HT neurons. These findings were interpreted as an early non-cell autonomous role for $E n$ in serotonergic development (Simon et al., 2005). Recent microarray studies of flow-sorted 5-HT neurons demonstrated, however, that En1 and En2 are actually expressed in rostral postmitotic 5-HT neurons (Wylie et al., 2010). These findings suggest that En may play not only early patterning roles in serotonergic development but also intrinsic roles in maturing 5 - $\mathrm{HT}$ neurons. To investigate this possibility, we conditionally targeted En specifically in maturing 5-HT neurons. Our findings demonstrate that En1 plays a dominant role over En2 in the cytoarchitectural organization, maintenance, and survival of a subset of rostral 5-HT neurons that form the DRN.

\section{Materials and Methods}

Mice. Mouse breeding and housing procedures were approved by the Case Western Reserve University School of Medicine Institutional Animal Care Committee in compliance with the National Institutes of Health Guide for the Care and Use of Laboratory Animals.

Compound $E n 1^{\text {flox/flox }} ; E n 2^{\text {flox/flox }}$ mice were a gift from Alexandra Joyner (Sloan-Kettering Institute, New York, NY). These mice were initially crossed to a line of mice (ePet-Cre;R26R) carrying the ePet-Cre transgene (Scott et al., 2005b) and the ROSA R26RLacZ (abbreviated $R 26 R)$ locus (Soriano, 1999). We generated three lines from this cross: (1) En1 $1^{\text {flox/flox }} ;$ ePet-Cre;R26R (En1 $\left.{ }^{5 H T C K O}\right),(2) E n 2^{\text {flox }}$ flox $; e P e t-C r e ;$ $R 26 R\left(E n 2^{5 H T C K O}\right)$, and (3) compound En $1^{\text {flox fllox }} ; E n 2^{\text {flox/flox }} ; e P e t-C r e$; $R 26 R\left(E n 1 / 2^{5 H T C K O}\right)$. The ePet-Cre;R26R mice used for controls were generated from a cross between En1 $1^{\text {flox/flox }} ;$ ePet-Cre;R26R and En $2^{\text {flox/flox }}$; ePet-Cre;R26R mice, followed by an intercross of their En $1^{\text {flox } /+} ; E n 2^{\text {flox } /}$ $+; e P e t-C r e ; R 26 R$ offspring. From these matings, we identified mice with wild-type En alleles, which were used for additional matings. This scheme allowed us to retain a similar genetic background among the En conditionally targeted mice that were used in experiments. En $1^{\text {flox/+ }} ; E n 2^{\text {flox/flox }}$ and $E n 1^{\text {flox/flox }} ; E n 2^{\text {flox/+ }}$ mice were generated from a mating between a compound En $1^{\text {flox/flox }} ;$ En $2^{\text {flox/flox }}$ mouse and either an En1 $1^{\text {flox/flox }}$ or an $E n 2^{f l o x / f l o x}$ mouse. Mice were maintained on a mixed genetic background of Swiss Webster, C57BL/6, and SJL. Because there is the potential that targeting efficiency would differ depending on expression from either one or two ePet-Cre alleles, only one parent in each mating had the ePet-Cre transgene. The ePet-EYFP transgene (Scott et al., 2005b) was also present in some of the experimental mice for immunohistochemical detection of 5-HT neurons and for their purification by flow cytometry.

Littermates with matched $E n^{f l o x}$ alleles in the absence of $e P e t-C r e$ were used as controls for all experiments that did not include $L a c Z$ analysis. Counts of DRN 5-HT neurons indicated comparable numbers in ePet$C r e ; R 26 R$ mice and mice with various En floxed allele combinations. In $L a c Z$ analyses, control mice were age matched between litters. Experimental and control mice 3 weeks or older were sex matched.

Histology. Postnatal mice were anesthetized using avertin $(0.5 \mathrm{~g}$ of tribromoethanol/39.5 $\mathrm{ml}$ of $\mathrm{H}_{2} \mathrm{O}+0.31 \mathrm{ml}$ of tert-amyl alcohol). Adolescent and adult mice were transcardially perfused with ice-cold PBS, $\mathrm{pH} 7.4$, followed with ice-cold 4\% paraformaldehyde (PFA) in PBS, $\mathrm{pH}$ 7.4, for 10 or $20 \mathrm{~min}$. The brains were removed and postfixed for $2 \mathrm{~h}$ on ice. Newborn mice were transcardially perfused with PBS and fixed in $4 \%$ PFA for $1 \mathrm{~h}$ on ice. Embryos were collected from timed pregnant mice and fixed in 4\% PFA for $1 \mathrm{~h}$. All tissues were cryoprotected in $20 \%$ sucrose in PBS overnight at $4^{\circ} \mathrm{C}$. Embryo and early postnatal tissues were embedded in O.C.T. Compound (Tissue-Tek) and stored at $-80^{\circ} \mathrm{C}$. Tissue sections $(20 \mu \mathrm{m})$ were obtained using a freezing microtome (adolescent and adult) or cryostat (embryonic and early postnatal), mounted onto SuperFrost Plus slides (Thermo Fisher Scientific), and dried at room temperature for $2 \mathrm{~h}$. X-gal staining was performed as described previously (Scott et al., 2005a). In situ hybridizations were performed as described previously (Wylie et al., 2010).

For fluorescent immunohistochemistry, the tissue sections were washed three times in PBST $(1 \times$ PBS, pH 7.4, and 0.1\% Triton X-100) and incubated in blocking solution (PBST with $0.3 \%$ Triton X-100 and $5 \%$ normal serum) for $\geq 1 \mathrm{~h}$. Newborn mouse sections were permeabilized with methanol for $30 \mathrm{~min}$ before blocking with M.O.M. kit (Vector Laboratories). Before caspase- 3 staining, sections underwent antigen retrieval in $\sim 95^{\circ} \mathrm{C}$ citrate buffer for $10 \mathrm{~min}$, cooled for $30 \mathrm{~min}$, and blocked with $2 \%$ normal serum. Tissue was incubated with primary antibodies in blocking solution overnight at $4^{\circ} \mathrm{C}$. The next day, the tissue was washed three times in PBST and incubated in secondary antibodies in blocking solution for $2 \mathrm{~h}$ covered at room temperature. After sections were washed three times, coverslips were attached with PermaFluor Mountant (Thermo Fisher Scientific). Antibodies used were Tph (mouse monoclonal anti-tryptophan hydroxylase, 1:100; Sigma), 5-HT (rabbit polyclonal anti-5-HT, 1:10,000; Immunostar), $\beta$-gal (chicken polyclonal anti- $\beta$ galactosidase, 1:1000; Abcam), pan-En (rabbit anti-Enhb-1; gift from Alexandra Joyner, Sloan-Kettering Institute), cleaved caspase-3 (rabbit monoclonal anti-cleaved caspase-3, 1:100; Cell Signaling Technology), and Alexa Fluor-488, Alexa Fluor-594, and Alexa Fluor-350 (1:500; Invitrogen). Images were obtained using an Olympus Optical BX51 microscope and SPOT camera (Diagnostic Instruments) or a Carl Zeiss LSM 510 Meta confocal microscope. Images were processed using Adobe Photoshop (Adobe Systems).

Cell counting. 5-HT neurons were identified with 5-HT immunostaining at embryonic ages and with Tph immunostaining at postnatal ages. $R 26 R L a c Z$ expression was detected with either X-gal staining or $\beta$-gal immunostaining. All 5-HT neuron counts were obtained from every other section through the rostral hindbrain or entire rostrocaudal extent of the DRN or MRN. In E12.5 and E14.5 embryos, 5-HT neurons were counted in the rostral hindbrain [rhombomeres 1 (r1) to $\mathrm{r} 3$ ] from the mid-hindbrain boundary to the pontine flexure. At late embryonic and postnatal ages, 5-HT neurons were counted in the DRN and/or MRN. A computer program was developed to permit blinded manual counting of Tph-immunostained and LacZ-marked neurons in images captured from experimental and control tissue sections. To quantify the distribution of targeted 5-HT neurons in the P0 DRN, a template was generated to divide each image into midline and lateral sectors. The width of the midline was defined as the width of B6 and caudal B7, which was consistent across multiple control mice. While blinded to the genotype, the template was positioned over each image and aligned to the shape of the nucleus, and then the number of cells within each sector was recorded. From these counts, the percentage of cells within either the midline sector or the adjacent lateral sector was determined and averaged across multiple animals for each rostrocaudal level of the DRN. No difference in the overall numbers of cells was observed in any of the rostrocaudal regions examined between the genotypes. For analysis of cleaved caspase- 3 expression, the DRN was identified with $\beta$-gal immunofluorescence and caspase-3-expressing $\left(\right.$ caspase $\left.-3^{+}\right) / \mathrm{DAPI}^{+}$cells were counted from imaged control and experimental mice.

HPLC. Tissues were dissected from E12.5, newborn (P0), 3-week-old, 6-week-old, and 12-week-old mice. Adolescent and adult mice were anesthetized with avertin and underwent cervical dislocation. Brains were quickly removed and placed in dry ice. When partially frozen, a sterile razor blade was used to cut at bregma area $-2.92 \mathrm{~mm}$ to separate the forebrain and then again at bregma area $-5.68 \mathrm{~mm}$ to isolate midbrain tissue. The cortex was removed from the midbrain tissue, which was quickly returned to dry ice. Newborn mice were decapitated, and the brain was exposed and cut at bregma area $-2.92 \mathrm{~mm}$ to separate forebrain tissue from midbrain and hindbrain tissue. E12.5 embryos were collected as described, and the neural tube was dissected between the mesencephalic flexure and the pontine flexure. Tissues were stored at $-80^{\circ} \mathrm{C}$ for up to 2 months before HPLC analysis. For adolescent and adult mice, seven males and seven females were used for each age group and genotype. Dissected tissues were sent for HPLC analysis to the Neurochemistry Core Laboratory in the School of Medicine at Vanderbilt University (Nashville, TN).

Isolation of rostral domain 5-HT neurons. E12.5 En1/2 ${ }^{5 H T C K O} ;$ ePetEYFP and En1 $1^{\text {flox/flox }} ; E n 2^{\text {flox/flox }} ;$ ePet-EYFP embryos were obtained from $E n 1^{\text {flox/flox }} ; E n 2^{\text {flox/flox }}$ crosses in which one parent contained ePet-Cre and/or ePet-EYFP. ePet-EYFP ${ }^{+}$E12.5 embryos were collected into icecold L-15 media (Invitrogen) by visualization under an inverted fluores- 
cent dissecting microscope. Yellow fluorescent protein (YFP) fluorescence between the mesencephalic flexure and pontine flexure was used to dissect a portion of the neural tube containing the entire domain of rostral hindbrain 5-HT neurons. Embryos were genotyped and embryos of the same genotype were combined before mechanical dissociation by trituration. Cells were sorted on a BD Biosciences FACS Aria digital cell sorter using previously established conditions for embryonic 5-HT neurons (Wylie et al., 2010). Cells were collected in Trizol (Invitrogen) and stored at $-80^{\circ} \mathrm{C}$ until RNA extraction. A typical sort yielded $\sim 10,000 \mathrm{YFP}^{+}$cells/embryo. Cells from multiple sorts were combined to produce biological replicates of $\sim 50,000 \mathrm{YFP}^{+}$rostral hindbrain neurons. A total of 50,000 $\mathrm{YFP}^{-}$rostral hindbrain cells were also collected from each sort.

Real-time qRT-PCR analysis. RNA was extracted in Trizol reagent (Invitrogen) according to the manual of the manufacturer. All RNA from each sample was used for first-strand cDNA synthesis (Roche). Real-time qRT-PCR was conducted in triplicate using a $25 \mu \mathrm{l}$ reaction of FastStart Universal SYBR Green Master (Roche), specific primers, and $1 \mu \mathrm{l}$ of cDNA. All real-time qRT-PCR reactions were performed for 40 cycles with an annealing temperature of $60^{\circ} \mathrm{C}$ on StepOnePlus Real-Time PCR System (Applied Biosystems). Relative gene expression was determined using published protocols (Pfaffl et al., 2002). The primers used were as follows: for En1, forward primer, GGGTCTACTGCACACGCTATT and reverse primer, TTTTCTTCTTTAGCTTCCTGGTG; En2, forward primer, GCTAATCTGACCGGCCTTC and reverse primer, GCTTGTCCTCTTTGTTAGGGTTC; serotonin transporter (Sert), forward primer, CAAGTTCAACAACAACTGTTACCAA and reverse primer, TAGCCAAGCACCGTGAAGAT; Pet-1, forward primer, AACATGTACCTGCCAGATCC and reverse primer, CCAGGAGAAACTGCCACAAC; and Actin (reference gene), forward primer, TCCTAGCACCATGAAGATCAAGATCA and reverse primer, GCAGCTCAGTAACAGTCCG.

Statistics. Statistical analyses were performed on normally distributed data using a $t$ test for single time point comparisons between control and mutant mice or a two-way ANOVA with Bonferroni's multiple comparison test for comparison across multiple ages or genotypes. For analysis of the distribution of LacZ-marked neurons in the P0 DRN, a two-way repeated-measures ANOVA with Bonferroni's multiple comparison test was used. Statistical analysis was performed using Excel and GraphPad Prism 5.

\section{Results}

\section{$E n 1$ and $E n 2$ are expressed in postmitotic 5-HT neurons}

Gene expression profiling of flow-sorted 5-HT neurons at E12.5 revealed strong expression of En1 and En2 in rostral but not caudal hindbrain 5-HT neurons (Wylie et al., 2010). In addition, immunohistochemical verification of En expression with a pan-En antibody indicated En protein expression in postmitotic 5-HT neurons at least through E14.5 (Wylie et al., 2010). We used in situ hybridization to comprehensively map the individual spatiotemporal expression patterns of En1 and En2 in the developing rostral hindbrain. Moderate expression of $E n 1$ and strong expression of En2 was detected throughout the mid-hindbrain region at E11.5, a stage when serotonergic neurogenesis is complete in the rostral hindbrain (Fig. 1A,B). Expression of En1 and En2 rostral to the mid-hindbrain boundary was detected in the mesencephalic region in which DA neurons are born. En1 expression was also present caudal to this boundary in which developing rostral 5-HT neurons are located. This pattern of En1 expression is consistent with previous findings from mapping of lineage boundaries using an En1-Cre knock-in allele, which suggested that En1 expression in the rostral hindbrain is restricted to $\mathrm{r} 1 \mathrm{Li}$ et al., 2002; Zervas et al., 2004). The pattern of En2 expression in the rostral hindbrain overlapped with that of En1, although the En2 expression domain appeared to extend more caudally than that of En1 (Fig. 1A,B). However, at E14.5, En2 expression began to diminish but En1 expression became more prominent in the rostral hindbrain domain (Fig. 1C,D). At E17.5, En1 expression persisted in the rostral domain in which migrating 5-HT neurons were located. In contrast, En2 expression became undetectable in the rostral hindbrain at this stage, although its expression persisted in the mesencephalic region anterior to the mid-hindbrain boundary (Fig. 1E, F). Immunohistochemistry with a pan-En antibody that recognizes both En1 and En2 (Davis et al., 1991) detected En protein expression in the nuclei of E14.5 ePet$\mathrm{EYFP}^{+}$5-HT neurons in the rostral hindbrain (Fig. 1G).

In situ hybridization of brain sections from 3-week-old wildtype mice (Fig. $2 A, B$ ) revealed strong expression of $E n 1$ in what appeared to be all 5-HT neurons within the DRN but in only a subset of 5-HT neurons that populate the MRN. In contrast, En2 expression was not detected in the postnatal DRN and MRN, although its expression was present in the midbrain ventral tegmental area (VTA) and substantia nigra (SN) (data not shown). Coimmunostaining of brain sections from 3-week-old mice with the anti-pan-En antibody and an anti-Tph antibody detected nuclear En protein in all 5-HT neurons of the DRN (Fig. 2C) and in 5-HT neurons located in the dorsal, but not ventral, portions of the MRN (Fig. 2D). Similar results were obtained with sections from adult mice (data not shown). These findings demonstrate that both En1 and En2 are expressed in the rostral hindbrain through the stage of 5-HT neuron differentiation and into the stage of 5-HT neuron maturation. However, their respective temporal expression patterns dramatically diverge subsequently: En1 expression persists into the postnatal period in all 5-HT neurons of the DRN and some 5-HT neurons of the MRN, whereas serotonergic En2 expression is present only up to mid-fetal stages of 5-HT neuron maturation.

\section{Conditional targeting of $\mathbf{E n}$ in maturing 5-HT neurons}

The persistent expression of En $1 / 2$ in postmitotic 5-HT neurons raises the possibility that these homeodomain factors are required for intrinsic regulation of 5-HT neuron development after these cells acquire their serotonergic identity. To investigate this hypothesis, we used a conditional targeting strategy to knock-out En expression specifically in maturing postmitotic 5-HT neurons but preserve their function at earlier stages of development (Fig. $3 A$ ). This strategy was achieved by crossing the ePet-Cre transgene (Scott et al., 2005b) into compound En1 $1^{\text {flox/flox }}$;En $2^{\text {flox/flox }}$ mice (Sgaier et al., 2007; Cheng et al., 2010) to generate 5-HT neuron-specific En1/2-targeted mice (En1/2 $\left.{ }^{5 \text { HTCKO }}\right)$. Pet-1 and ePet-Cre are not expressed until after the proliferating progenitor stage of serotonergic neurogenesis (Hendricks et al., 1999; Scott et al., 2005b; Hawthorne et al., 2010). In addition, birthdating with BrdU has shown that this stage of neurogenesis ceases in $\mathrm{r} 1$ at approximately E10.5, which is $\sim 1 \mathrm{~d}$ before the termination of serotonergic neurogenesis in $\mathrm{r} 2$ and $\mathrm{r} 3$ of the rostral hindbrain (Jacob et al., 2007). We showed previously that Pet-1, Lmx1b, Tph2, Sert, and 5-HT expression were normal at E11.5 in the rostral hindbrain of $e P e t-C r e$ conditionally targeted Pet- $1^{\text {flox/- }}$ or Lmx $1 b^{\text {flox/flox }}$ mice (Zhao et al., 2006; Liu et al., 2010). At E12.5, however, expression of all of these serotonergic markers was substantially reduced in these conditional mutant mice, showing that ePet-Cre is effective in targeting serotonergic gene expression 1-2 $\mathrm{d}$ after rostral 5-HT neurogenesis (Zhao et al., 2006; Liu et al., 2010).

Real-time qRT-PCR analysis of gene expression revealed an $85 \%$ loss of En1 and En2 expression at E12.5 in $\mathrm{YFP}^{+}$5-HT neurons purified by flow cytometry (Wylie et al., 2010) from En1/2 ${ }^{5 H T C K O}$;ePet-EYFP mice compared with levels in En $1^{\text {flox/flox; }}$; $E n 2^{\text {flox/flox }} ;$ ePet-EYFP controls (Fig. $3 B$ ). In contrast, the level of 


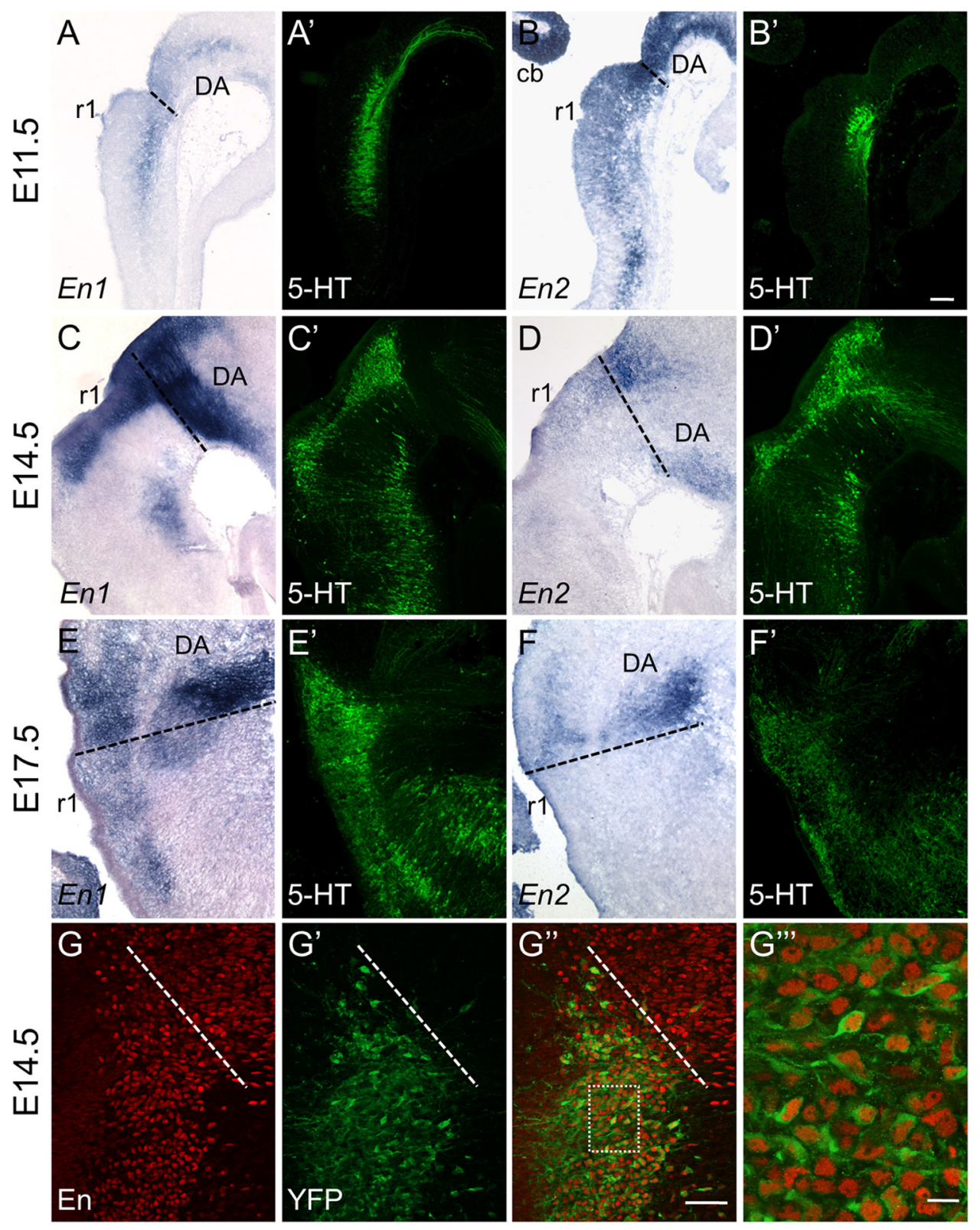

Figure 1. Spatiotemporal expression patterns of $E n 1$ and $E n 2$ in the rostral hindbrain. $\boldsymbol{A}-\boldsymbol{F}$, In situ hybridization to detect $E n 1(\boldsymbol{A}, \boldsymbol{C}, \boldsymbol{E})$ or $E n 2(\boldsymbol{B}, \boldsymbol{D}, \boldsymbol{F})$ transcripts and immunohistochemistry to detect 5-HT $\left(\boldsymbol{A}^{\prime}-\boldsymbol{F}^{\prime}\right)$ on adjacent sagittal sections at the indicated stages. $\mathbf{G}-\boldsymbol{G}^{\prime \prime \prime}$, Coimmunohistochemical staining for pan-En and YFP in ePet-EYFP transgenic embryos. $\boldsymbol{G}^{\prime \prime}$, Merge of images in $\boldsymbol{G}$ and $\mathbf{G}^{\prime}$. $\mathbf{G}^{\prime \prime \prime}$, Higher-magnification image of boxed region in $\boldsymbol{G}^{\prime \prime}$. cb, Cerebellum; DA, mesencephalic domain of dopaminergic neurons. Dashed line indicates the midbrain- hindbrain boundary. Scale bars: (in $\left.\boldsymbol{B}^{\prime}\right) \boldsymbol{A}-\boldsymbol{F}, 100 \mu \mathrm{m}$; (in $\left.\boldsymbol{G}^{\prime \prime}\right) \mathbf{G}-\boldsymbol{G}^{\prime \prime}, 50 \mu \mathrm{m} ; \boldsymbol{G}^{\prime \prime \prime}, 10 \mu \mathrm{m}$.

En expression was not altered in neighboring $\mathrm{YFP}^{-}$non-5-HT cells (Fig. 3B). Targeting efficiency and specificity was confirmed with pan-En immunostaining in 5-HT neurons, which showed that En immunoreactivity was absent in virtually all targeted 5-HT neurons permanently marked through Cre-mediated recombination of the ROSA R26RLacZ allele (Fig. 3C).

\section{En controls maturation of DRN cytoarchitecture}

A critical step in the development of the 5-HT system is the formation of the DRN, in which greater than half of all rodent ascending 5-HT neurons are located (Vertes and Crane, 1997). Initial movement of 5-HT neuron cell bodies away from the ventricular zone occurs through the process of somal translocation (Hawthorne et al., 2010) through which newly born 5-HT neurons migrate to more ventral portions of the neural tube. This primary migratory event creates bilateral clusters of 5-HT neurons along the dorsoventral axis as shown in the transverse section presented in Figure 5, $C$ and $D$. The mature cytoarchitectural organization of the DRN arises through subsequent secondary migration of 5-HT neuron cell bodies toward the midline, resulting in the fusion of the bilateral serotonergic clusters (Levitt and Moore, 1978) as presented in Figure 4, A, E, and $I$. Formation of the mature DRN is normally completed just before birth (Lidov and Molliver, 1982b; Wallace and Lauder, 1983). Virtually nothing is known, however, about the regulatory mechanisms involved in DRN formation and whether intrinsic transcriptional mechanisms are involved. Indeed, it has been suggested that DRN formation occurs passively as a result of extrinsic morphological changes in the developing brain ( $\mathrm{Li}$ dov and Molliver, 1982b). 

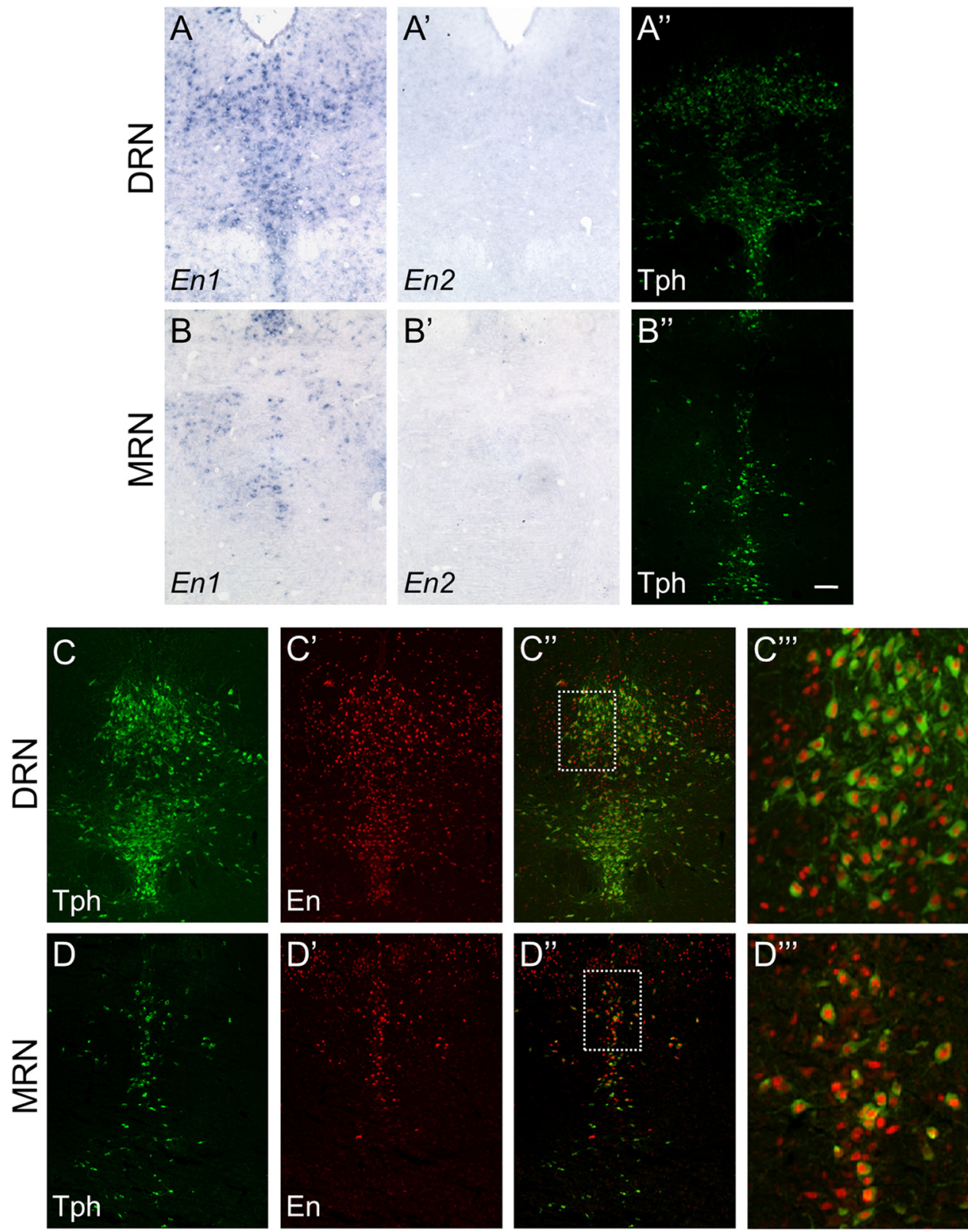

Figure 2. En1 expression in 5-HT neurons is maintained postnatally. $\boldsymbol{A}, \boldsymbol{B}$, In situ hybridization to detect $E n 1(\boldsymbol{A}, \boldsymbol{B})$ or $E n 2\left(\boldsymbol{A}^{\prime}, \boldsymbol{B}^{\prime}\right)$ transcripts and immunohistochemical detection of Tph $\left(\boldsymbol{A}^{\prime \prime}, \boldsymbol{B}^{\prime \prime}\right)$ on adjacent coronal sections in the DRN $\left(\boldsymbol{A}-\boldsymbol{A}^{\prime \prime}\right)$ and MRN $\left(\boldsymbol{B}-\boldsymbol{B}^{\prime \prime}\right)$ at 3 weeks of age. $\boldsymbol{C}, \boldsymbol{D}$, Coimmunostaining with Tph $(\boldsymbol{C}, \boldsymbol{D})$ and pan-En $\left(\boldsymbol{C}^{\prime}, \boldsymbol{D}^{\prime}\right)$ antibodies in the DRN $\left(\boldsymbol{C}-\boldsymbol{C}^{\prime \prime \prime}\right)$ and MRN $\left(\boldsymbol{D}-\boldsymbol{D}^{\prime \prime \prime}\right)$ in 3-week-old mice. $\boldsymbol{C}^{\prime \prime}, \boldsymbol{D}^{\prime \prime}$, Merge of images in $\boldsymbol{C}$ and $\boldsymbol{C}^{\prime}$ or $\boldsymbol{D}$ and $\boldsymbol{D}^{\prime}$, respectively. $\boldsymbol{C}^{\prime \prime}, \boldsymbol{D}^{\prime \prime}$, Higher-magnification image of boxed region in $\boldsymbol{C}^{\prime}$ and $\boldsymbol{D}^{\prime \prime}$. Scale bar (in $\left.\boldsymbol{B}^{\prime \prime}\right) \boldsymbol{A}-\boldsymbol{D}, 100 \mu \mathrm{m}$.

Initial histological analyses suggested disorganization of DRN cytoarchitecture at the perinatal stage in En1/2 $2^{5 H T C K O}$ mutants. To facilitate a detailed investigation of this potential abnormality of DRN formation, 5-HT neurons were permanently marked by ePet-Cre-mediated recombination of the ROSA R26RLacZ allele (Soriano, 1999). Analyses of $\mathrm{LacZ}^{+}$5-HT neurons visualized with $\mathrm{X}$-gal staining in sections obtained from newborn En $1 / 2^{5 H T C K O}$ mice revealed disruption of DRN cytoarchitecture at multiple levels along its rostrocaudal axis (Fig. $4 B, F, J$ ). Counts of cells at these rostrocaudal levels revealed significant misplacement of $\mathrm{LacZ}^{+}$5-HT neuron cells bodies away from the midline (Fig. $4 M, N, O)$. However, the total number of cell bodies in the En1/ $2^{5 H T C K O}$ DRN was unchanged (see Fig. 9C). At the rostral end of the DRN in the midbrain, the bilateral clusters of $\mathrm{LacZ}^{+} 5-\mathrm{HT}$ neurons failed to reach the midline (Fig. 4, compare $A, B$ ), suggesting that these $E n$ mutant neurons were stalled in a primitive embryonic stage of DRN formation. The mis-positioned serotonergic cell bodies created a prominent gap (Fig. $4 B$, asterisks) at the midline compared with ePet-Cre;R26R controls (Fig. 4A,M). At more caudal levels of the midbrain DRN, En1/2 deficiency caused abnormal dense aggregations of LacZ-marked 5-HT neurons on either side of the midline (Fig. $4 F$, arrows vs $E$ ), producing a similar midline gap of cell bodies (Fig. $4 F$, asterisk, $N$ ). At the caudal end of the DRN in the pons, large numbers of LacZmarked 5-HT neuron cells bodies were laterally displaced to various extents within the surrounding ventrolateral periaqueductal gray, creating a ventral "bulge" of mis-positioned serotonergic cell bodies (Fig. 4J, filled arrowheads, $O$ ) and aberrant "winglike" structures in the dorsal B6 DRN (Fig. 4J, open arrowheads). The altered distribution of cells was not the result of delayed cytoarchitectural maturation because the abnormal cell aggregations and midline gaps persisted through 6 weeks of age (see Fig. 
A

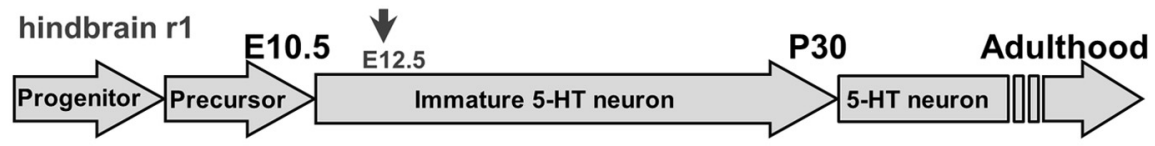

En1

\section{En2}

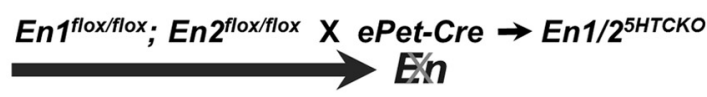

B

E12.5
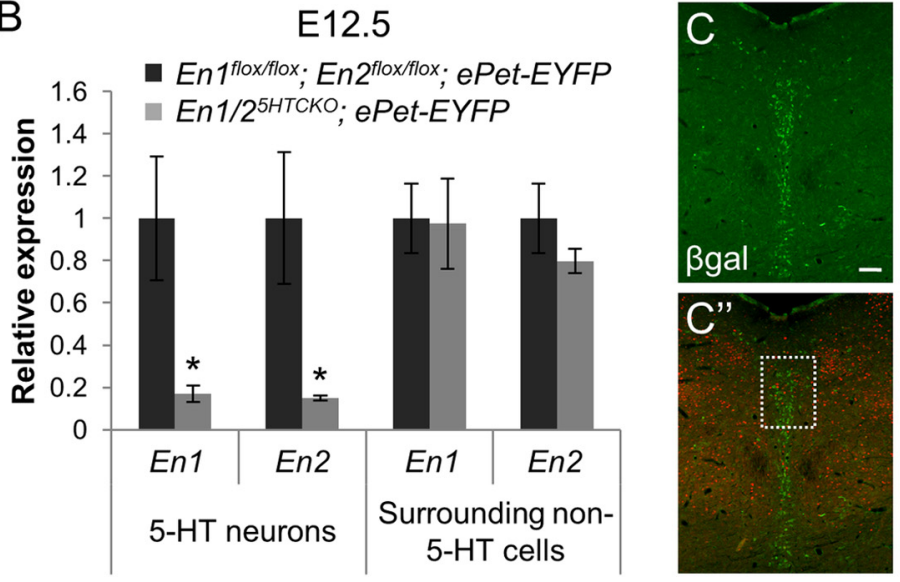

3 weeks

Figure 3. Conditional targeting of $E n 1 / 2$ in $5-H T$ neurons after neurogenesis. $\boldsymbol{A}$, Schematic displaying the timing of $E n 1 / 2$ conditional targeting relative to the stages of serotonergic $E n 1$ and En2 expression. $\boldsymbol{B}$, Real-time qRT-PCR analysis of $E n 1$ and $E n 2$

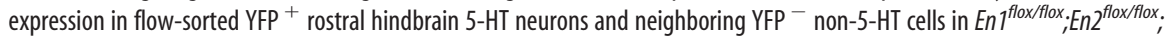
ePet-EYFP control and En 1/2 ${ }^{5 H T C K O}$;ePet-EYFP mice at E12.5. $n=4$ biological replicates per genotype. Data presented as mean \pm SEM; two-tailed $t$ test, ${ }^{*} p<0.05$. $\boldsymbol{C}$, Coimmunostaining with $\beta$-gal $(\boldsymbol{C})$ and pan-En $\left(\boldsymbol{C}^{\prime}\right)$ antibodies in the DRN of 3-week-old mice. $\boldsymbol{C}^{\prime \prime}$, Merge of the images in $\boldsymbol{C}^{\text {and }} \boldsymbol{C}^{\prime}$. $\boldsymbol{C}^{\prime \prime}$, Higher-magnification image of boxed region in $\boldsymbol{C}^{\prime}$. Scale bar, $100 \mu \mathrm{m}$.

$9 B$ and data not shown). We could not detect a defect in the cytoarchitecture of the MRN, perhaps because either En is not required for this maturation step in this raphe nucleus or expression of En in only a subset of MRN 5-HT neurons precluded detection of mispositioned $\mathrm{LacZ}$-marked neurons.

We next examined mice with different combinations of En conditional alleles and the ePet-Cre;R26R transgenes to investigate the relative requirements for $E n 1$ and $E n 2$ in DRN formation. Conditional targeting of both En1 alleles $\left(E n 1^{\text {flox/flox }} ; E n 2^{+/+}\right.$; ePet-Cre;R26R or En1 ${ }^{5 H T C K O}$ ) in a wild-type En2 background resulted in less severe but obvious positioning errors, particularly in the posterior DRN at P0 (Fig. $4 C, G, K$ ). However, no cell aggregates or midline gaps were observed in the DRN of these conditional mutant mice. This suggests that En2 can incompletely compensate for loss of En1. Targeting of one En2 allele and both En1 alleles $\left(E n 1^{\text {flox/flox }} ; E n 2^{\text {flox/+ }} ;\right.$ ePet-Cre;R26R) did not increase the severity of the cytoarchitectural defects (data not shown). In contrast to the less severe phenotype in En $1^{5 H T C K O}$ mice, conditional targeting of both En2 alleles $\left(E n 1^{+/+} ; E n 2^{\text {flox/flox }}\right.$; ePet-Cre;R26R or En $\left.{ }^{5 H T C K O}\right)$ in a wild-type En1 background did not affect midline distribution of $\mathrm{LacZ}^{+}$5-HT neurons compared with ePet-Cre;R26R controls (Fig. 4D,H,L). Furthermore, additional targeting of one En1 allele together with both En2 alleles $\left(E n 1^{f l o x /+} ; E n 2^{\text {flox/flox }} ; e P e t-C r e ; R 26 R\right)$ did not result in cytoarchitectural defects (data not shown). Thus, a single En1 allele is sufficient for normal cellular organization of the DRN. These findings suggest that En1 plays a primary role over En2 in DRN formation; however, because

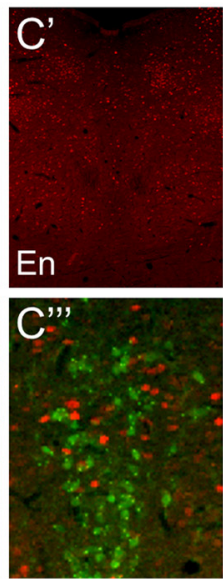

the En1/2 $2^{5 H T C K O}$ phenotype is more severe than $E n 1^{5 H T C K O}, E n 2$ must also contribute before being turned off before E17.5.

Because En1/2 were targeted after serotonergic neurogenesis, the disrupted formation of DRN cytoarchitecture was not likely the result of abnormal redistribution of sites of 5-HT neuron birth in $\mathrm{r} 1$, which was corroborated by the finding of a normal distribution of 5-HT neurons at E12.5 along rostrocaudal axis (Fig. $5 A, B$ ). In addition, aberrant primary migration of newborn 5-HT neurons away from the ventricular zone toward more ventral portions of the neural tube through somal translocation (Hawthorne et al., 2010) was not likely responsible for disruption of DRN cytoarchitecture because we found a normal bilateral distribution of newly born 5-HT neurons at E12.5 along the dorsoventral axis (Fig. $5 C, D)$. Our findings, therefore, suggest that cytoarchitectural maturation of the DRN depends on an intrinsic En-dependent regulatory program, which is required in postmitotic 5-HT neurons to control secondary cell body somal translocation or migration to the midline.

\section{$E n$ is required for perinatal maintenance of serotonergic neuron identity}

The reduced level of 5-HT at E12.5 in ePet-Cre directed conditionally targeted Pet- 1 and $L m \times 1 b$ mice (Zhao et al., 2006; Liu et al., 2010) demonstrated a requirement for these transcription factors in the early maintenance of 5-HT neuron identity. Thus, we next investigated whether En1/2 function might also be required for early maintenance of 5-HT neuron identity. Analyses of En1/2 $2^{5 H T C K O}$ mice and littermate $E n 1^{\text {flox/flox }} ; E n 2^{\text {flox/flox }}$ control mice in the E12.5 rostral hindbrain revealed that, in addition to the comparable distribution and numbers of 5-HT neurons (Fig. 5A-E), tissue 5-HT levels in the rostral hindbrain determined by HPLC were not significantly different in En $1 / 2^{5 H T C K O}$ and littermate En ${ }^{\text {flox/flox }} ;$ En $2^{\text {flox/flox }}$ control mice (Fig. $5 F$ ). Furthermore, we detected similar levels of Pet-1, Sert, and $L m \times 1 b$ mRNAs in FACSsorted E12.5 $\mathrm{YFP}^{+}$5-HT neurons obtained from En1/2 ${ }^{5 H T C K O}$; ePet-EYFP mice and En1 $1^{\text {flox/flox }} ;$ En $2^{\text {flox/flox }} ;$ ePet-EYFP control mice (Fig. $5 G$ and data not shown). These findings further support the conclusion that 5-HT neuron numbers and phenotype are not altered in En1/2 $2^{5 H T C K O}$ mice at E12.5. Thus, unlike Pet-1 and $L m \times 1 b, E n 1 / 2$ do not appear to be required for early maintenance of 5-HT neurons.

We then investigated with either 5-HT or Tph immunostaining whether loss of En1/2 affected serotonergic identity at later stages of life (Fig. 6). Interestingly, a large deficit in the number of Tph-immunoreactive neurons in the DRN was detected at 6 weeks of age (Fig. $6 A, B$ ). To determine when the loss of serotonergic identity begins, we counted the number of identifiable 5-HT neurons at several fetal and postnatal stages. This analysis showed that a significant deficit in the number of $5-\mathrm{HT}^{+}$neurons was evident beginning at E16.5 in the rostral hindbrain of En1/ $2^{5 H T C K O}$ mice and that this deficit continued to worsen into the 
early postnatal period (Fig. 6E). Quantitation of the number of $\mathrm{Tph}^{+}$neurons (Fig. $6 E$ ) in the DRN of En1/2 ${ }^{5 H T C K O}$ mice from $\mathrm{P} 0$ through 23 weeks of age indicated that the deficiency of 5- $\mathrm{HT}^{+}$neurons appeared to be maximal at birth. At 23 weeks of age, we found a $55 \%$ deficit in the number of $\mathrm{Tph}^{+}$cells in En1/2 $2^{\text {SHTCKO }}$ mice, which was not significantly different from the $43 \%$ deficit at birth. The deficit in $\mathrm{Tph}^{+}$neurons was uniform across all rostrocaudal levels of the En1/2 $2^{5 H T C K O}$ DRN. A much more modest, but significant, $18 \%$ deficit was also found in the adult En $1 / 2^{5 H T C K O}$ MRN (Fig. $6 C, D, F$ ), which is consistent with En1 expression in a subset of MRN 5-HT neurons (Fig. 2). Consistent with the lack of En1/2 expression in medullary 5-HT neurons, the number of $\mathrm{Tph}^{+}$neurons in caudal 5-HT nuclei was similar between En1/2 ${ }^{5 H T C K O}$ and littermate control mice (data not shown).

HPLC analyses in control mice revealed that midbrain and forebrain 5 - $\mathrm{HT}$ levels significantly increased through the early postnatal period and into young adulthood (Fig. 7). In comparison, analysis of En1/2 ${ }^{5 H T C K O}$ mice revealed significant deficits in 5-HT levels (Fig. 7), consistent with the loss of Tphimmunoreactive neurons. The level of forebrain 5 -HT in neonates was $60 \%$ of wild-type levels. At 3 weeks of age, the deficit stabilized at $50 \%$ of wild-type levels. Moreover, the normal rise in forebrain 5-HT levels seen in control animals was attenuated in En1/2 $2^{5 H T C K O}$ mice, particularly in the early postnatal period. A similar deficit in 5-HT levels was detected in dissected midbrain tissue, in which DRN and MRN cell bodies are located. However, 5-HT levels were normal at birth in En1/2 $2^{\text {SHTCOO }}$ midbrain (Fig. 7), perhaps because of nearly normal numbers of 5-HT neurons in the MRN and B9 clusters. Similar to the trajectory of forebrain 5-HT levels, the normal postnatal rise in midbrain 5-HT levels was also attenuated in En $1 / 2^{5 H T C K O}$ mice, particularly in the early adolescent period.

Consistent with extinguished En2 expression during fetal life, conditional targeting of both $E n 2$ alleles ( $E n 2^{5 H T C K O}$ ) had no effect on the number of Tph ${ }^{+}$cells at 6 weeks of age (Fig. $8 A$ ). Similarly, targeting both En2 alleles and one En1 allele $\left(E n 1^{\text {flox/ }^{\prime}} ; E n 2^{\text {flox/flox }} ;\right.$ ePet-Cre;R26R) did not result in a loss of $\mathrm{Tph}^{+}$cells at 6 weeks. Thus, a single En1 allele was sufficient for maintenance of 5-HT neuron identity. In contrast, a single En2 allele was not sufficient to maintain 5-HT neuron identity, because comparable deficits in the number of $\mathrm{Tph}^{+}$neurons were detected in both En1/2 $2^{5 H T C K O}$ and En $1^{\text {flox/flox }} ;$ En $2^{\text {flox/+ }} ;$ ePet-Cre;

\section{Rostral}
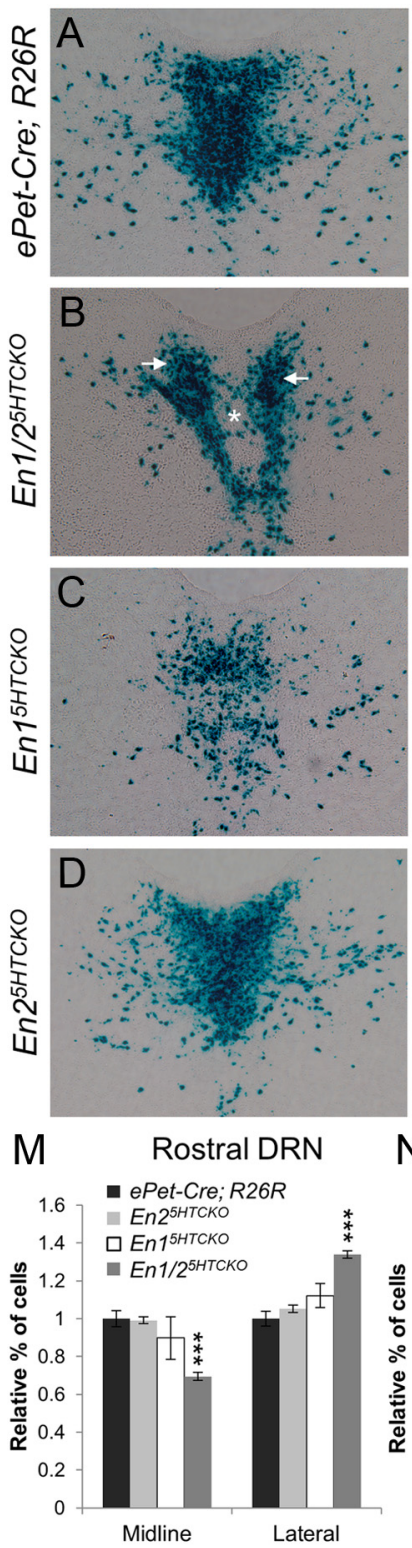
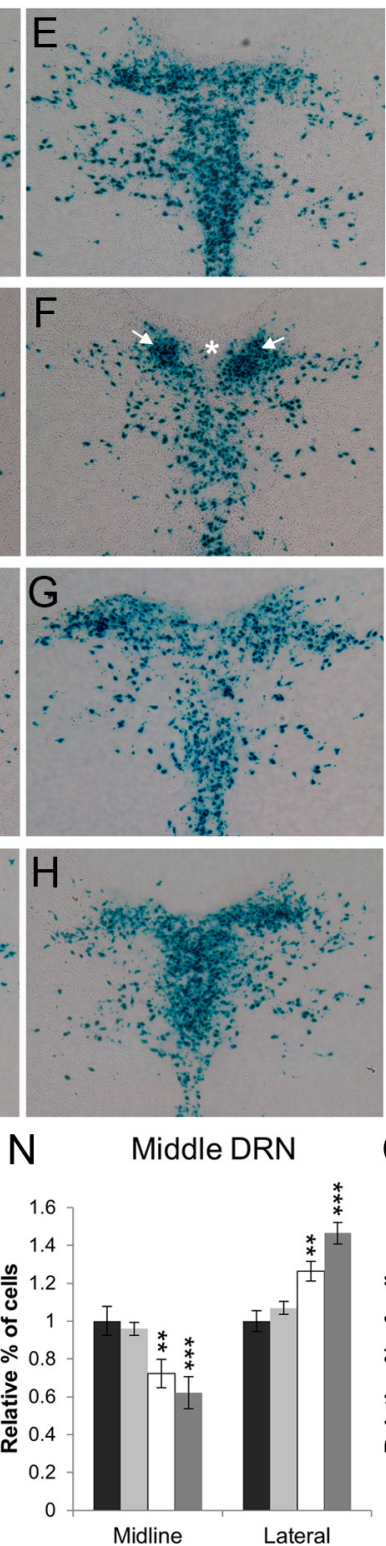
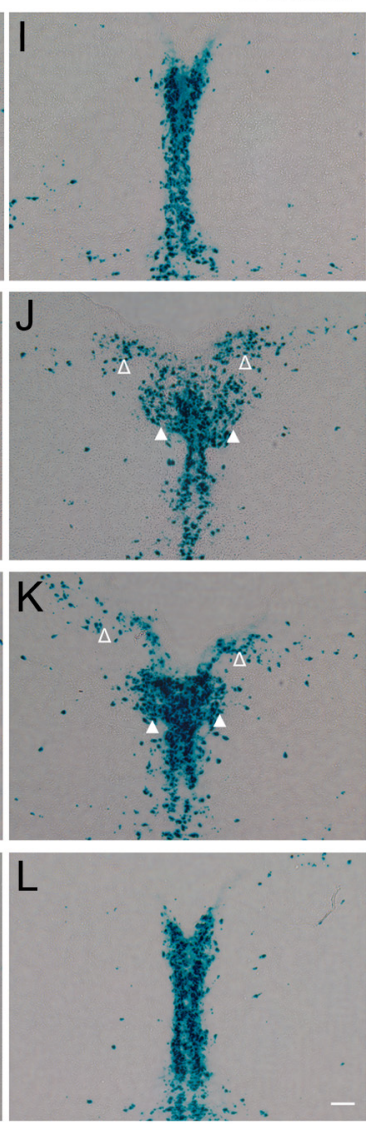

O Caudal DRN

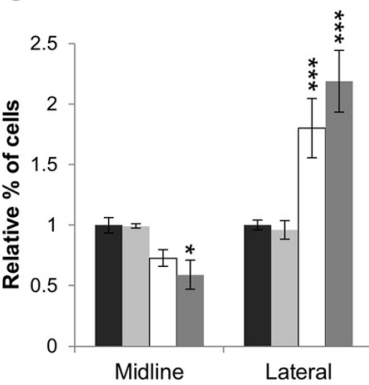

Figure 4. En is required in rostral postmitotic 5-HT neurons to regulate formation of the DRN. $A-L, X$-gal detection of $L a c Z^{+}$ 5-HT neurons on coronal sections at three different rostrocaudal levels of the DRN in the indicated genotypes at P0: $A-D, D R N$ (rostral B7) ventral to the periaqueductal gray; $\boldsymbol{E}-\boldsymbol{H}, \mathrm{DRN}$ (posterior B7) ventral to the periaqueductal gray; and $\boldsymbol{I}-\boldsymbol{L}$, posterior DRN (B6) in the pons. Arrows indicate abnormal aggregation of 5-HT neurons in the En $1 / 2^{5 H T C K O}$ DRN. Asterisks indicate midline gap in the distribution of 5-HT neurons in the En1/25HTCKO DRN. Filled arrowheads indicate misplaced LacZ ${ }^{+}$cells that form a bilateral bulge of mutant 5-HT neurons. Open arrowheads indicate abnormal wing-like structures of misplaced mutant 5-HT neurons. Scale bar: $\boldsymbol{A}-\boldsymbol{L}, 100 \mu \mathrm{m} . \mathbf{M}-\mathbf{0}$, The percentage of cells located either within the midline or lateral to the midline relative to the distribution in control ePet-Cre;R26R rostral DRN (rostral B7) $(\boldsymbol{M})$, middle DRN (caudal B7) ( $\boldsymbol{N}$ ), and caudal DRN (B6) (0) are shown for each indicated genotype. Indicated significance refers to statistical comparisons with ePet-Cre;R26R controls. The relative percentage of cells are statistically different between $E n 1 / 2^{5 H T C K O}$ and $E n 2^{5 H T C K O}$ in the rostral DRN (midline, $p<0.001$; lateral, $p<0.01$ ), middle DRN (midline, $p<0.01$; lateral, $p<0.001$ ), and caudal DRN (lateral, $p<0.001$ ). The relative percentage of cells in $E n 1 / 2^{5 H T C K O}$ and $E n 1^{5 H T C K O}$ are statistically different in the rostral DRN (midline, $p<0.05$; lateral, $p<0.05$ ). The relative

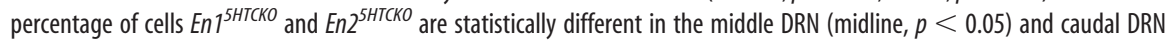
(lateral, $p<0.001)$. The distribution of cells is not different between $E n 2^{5 H T C K O}$ and ePet-Cre;R26R $(p>0.05)$. Counts were obtained from four to seven mice per genotype. Data are presented in mean $\pm \mathrm{SEM}$; two-way repeated-measures ANOVA with Bonferroni's post hoc tests. ${ }^{*} p<0.05,{ }^{* *} p<0.01,{ }^{* * *} p<0.001$.

$R 26 R$ mice. Importantly, conditional targeting of both $E n 1$ alleles in a wild-type $E n 2$ background $\left(E n 1^{\text {HTCKO }}\right)$ resulted in significantly decreased numbers of $\mathrm{Tph}^{+}$cells compared with littermate $E n$ flox/ $^{\text {for }}$ flox controls at 6 weeks. However, this deficit was not as severe as the 

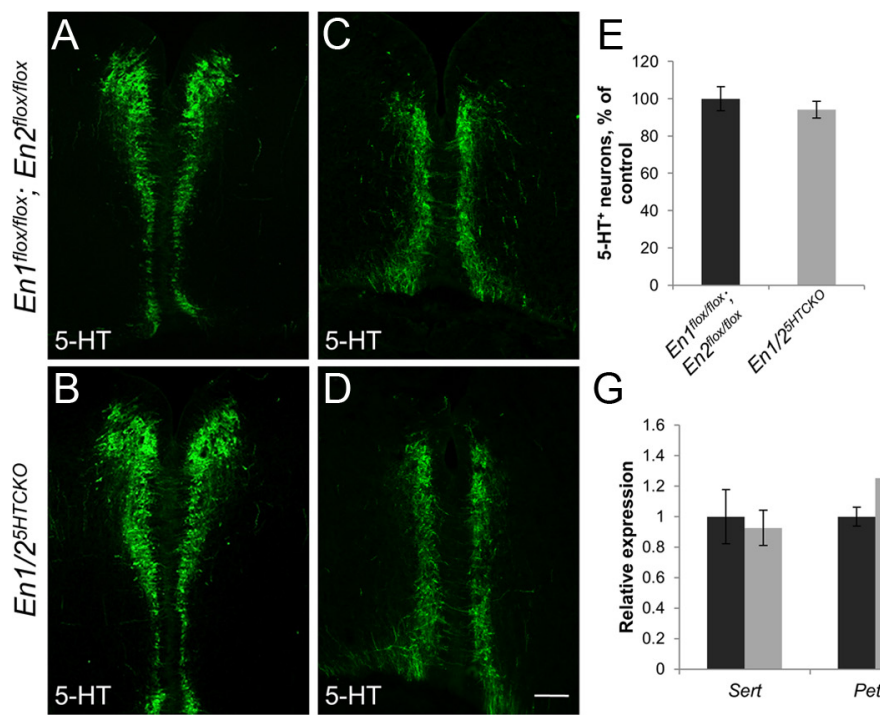

G

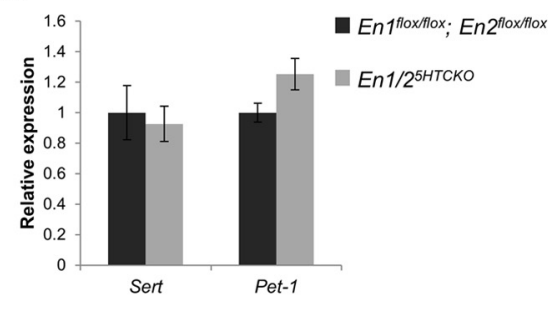

Figure 5. En is not required for early maintenance of 5-HT neuron identity. A-D, Immunohistochemical detection of 5-HT at E12.5 in En $1^{\text {flox/flox }}$,En2 $2^{\text {flox/flox }}$ control $(\boldsymbol{A}, \boldsymbol{C})$ and $E n 1 / 2^{5 H T C K O}(\boldsymbol{B}, \boldsymbol{D})$ mice along the rostrocaudal axis $(\boldsymbol{A}, \boldsymbol{B})$ and the dorsoventral axis $(\boldsymbol{C}, \boldsymbol{D})$. Scale bar, $100 \mu \mathrm{m}$. $\boldsymbol{E}$, Relative numbers of $5-\mathrm{HT}^{+}{ }^{+}$neurons at E12.5 in the rostral hindbrain of En $1^{\text {flox/flox }}$; En $2^{\text {flox/flox }}$ control and En $1 / 2^{\text {SHTKO }}$ mice. $n=3$ mice per genotype. $\boldsymbol{F}$, HPLC determination of 5-HT levels in the rostral hindbrain at E12.5 in En $1^{\text {flox/flox }}$;En $2^{\text {flox/flox }}$ control and En1/2 ${ }^{5 H T C K O}$ mice. $n \geq 15$ mice per genotype. G, Real-time qRT-PCR analysis of Sert and Pet-1

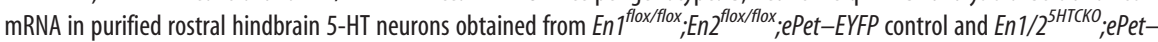
EYFP mice at E12.5. $n=3-5$ biological replicates per genotype. Data are presented as mean $\pm \mathrm{SEM}$; two-tailed $t$ test. $p>0.05$.
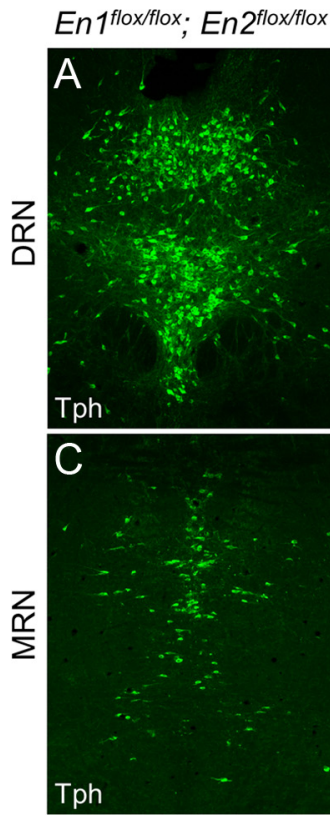
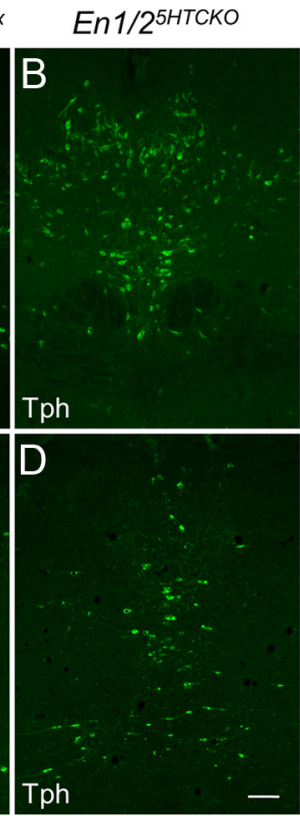

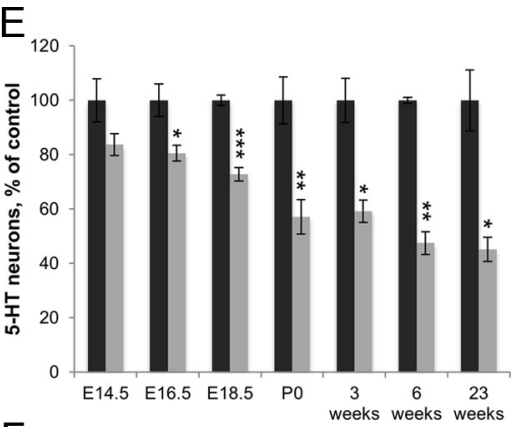

$\mathrm{F}$

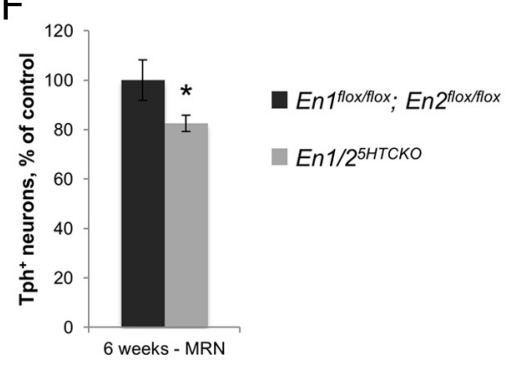

Figure 6. En is required for maintenance of serotonergic identity in the perinatal period. $A-D$, Tph immunostaining of the $D R N(A, B)$ and $M R N$ $(\boldsymbol{C}, \boldsymbol{D})$ on coronal sections in 6-week-old En $1^{\text {flox fflox }}$; En $2^{\text {floxfflox }}$ control $(\boldsymbol{A}, \boldsymbol{C})$ and $E n 1 / 2^{5 H T C K O}(\boldsymbol{B}, \boldsymbol{D})$ mice. Scale bar, $100 \mu \mathrm{m}$. $\boldsymbol{E}$, Relative numbers of 5 -HT neurons in the rostral hindbrain atE14.5 orDRN at the indicated embryonic stages and postnatal ages; $n=3-4$ mice per genotype per age for all analyses, except $n=8$ mice per genotype for E16.5. Embryonic 5-HT neurons were detected with 5-HT immunostaining and postnatal neurons with Tph immunostaining. Controls for 23-week-old mice were ePet-Cre;R26Rinstead of En $7^{\text {flox } f l o x}$, En $2^{\text {flox } f l o x}$. F, Relativenumber of Tph ${ }^{+}$neurons

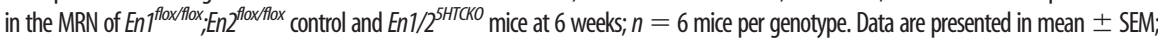
two-tailed $t$ test. ${ }^{*} p<0.05,{ }^{* *} p<0.01,{ }^{* * *} p<0.001$.

deficit seen in $E n 1 / 2^{5 H T C K O}$ mice (Fig. $8 A$ ), suggesting a contribution from En2. To investigate this further, we examined $E n 1^{5 H T C K O}$ mice at birth and found that, unlike the En1/2 ${ }^{5 H T C K O}$ mice (Fig. $6 E$ ), there was no difference in the number of $\mathrm{Tph}^{+}$cells relative to control numbers (Fig. 8 B). These findings show that, similar to En allele requirements for migration of 5-HT neuron cell bodies, $E n 1$ is the

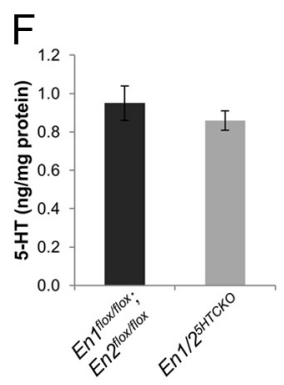

predominant functional En paralog in postmitotic 5-HT neurons for maintenance of identity, whereas En2 plays an early minor role before its RNA expression is extinguished by E17.5 (Fig. 1).

\section{En 1/2 deficiency causes 5-HT neuron cell death postnatally}

Because En1 and En2 are essential for survival of mesencephalic dopamine (mesDA) neurons (Simon et al., 2004), we followed the fate of LacZ-marked, En1/2deficient 5-HT neurons to determine whether these factors were also necessary for the survival of DRN 5-HT neurons. A significant deficit in the number of $\beta$-gal ${ }^{+}$ cells was detected in the adult DRN (Fig. $9 A, B)$. As expected from the finding of normal numbers of 5- $\mathrm{HT}^{+}$cells at E14.5, there was no deficit in the number of LacZ-marked cells at this stage (Fig. 9C). Moreover, despite the deficit in the number of $\mathrm{Tph}^{+}$cells in the En1/2 DRN at birth (Fig. $6 E$ ), there was no corresponding deficit in the number of $\mathrm{LacZ}$ labeled cells at this stage either (Fig. 9C). However, at P10, we found a $25 \%$ deficit in the number of $\beta$-gal ${ }^{+}$neurons in the

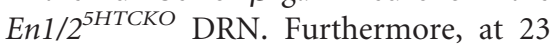
weeks of age, a $60 \%$ loss of $\beta$-gal ${ }^{+}$neurons was detected (Fig. 9C), indicating a loss of 5-HT neuron cell bodies comparable in number with the previous loss of $\mathrm{Tph}^{+}$cells in the mutant DRN (Fig. 6E).

To determine whether the loss of $\beta$-gal ${ }^{+}$cells in the En1/2 ${ }^{5 H T C K O}$ DRN was the result of apoptosis, we immunostained sections of mutant and control DRN from P10 mice with an antibody that specifically recognizes cleaved caspase- 3 , a validated marker of cells undergoing programmed cell death (Nicholson et al., 1995). We detected a significantly increased number of cleaved caspase-3 immunostained cells in the En $1 / 2^{5 \text { HTCKO }}$ DRN (Fig. 9D,E). Counts of cleaved caspase-3-immunoreactive cells indicated an $18 \%$ increase in En1/2 ${ }^{5 H T C K O}$ mice relative to ePet-Cre; R26R controls (Fig. 9E). A small number of cells immunostained for both cleaved caspase- 3 and $\beta$-gal were found in the En1/2 ${ }^{5 H T C K O}$ DRN but not in the ePet-Cre;R26R control DRN (Fig. $9 D$ ), thus confirming increased 5-HT neuron cell death in the mutant brain. These findings suggest that the loss of serotonergic identity in the En1/2 5 HTCKO DRN is followed by the apoptotic elimination of 5-HT neuron cell bodies.

\section{Discussion}

Our objective was to investigate possible intrinsic functions of En in postmitotic 5-HT neurons. Previous analyses implicated these 


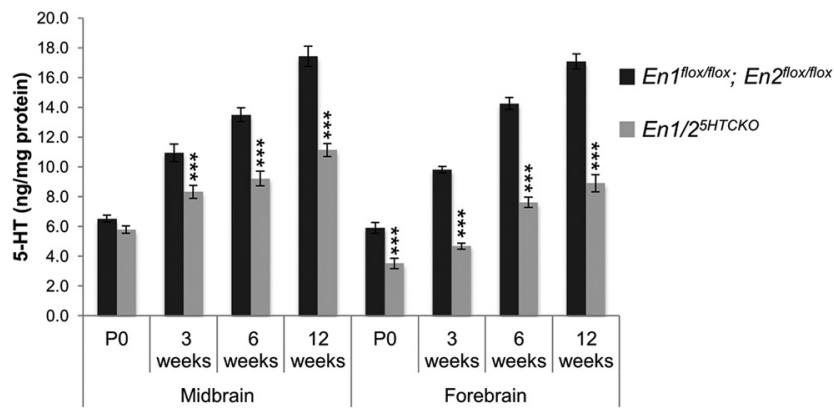

Figure 7. En is required in postmitotic 5-HT neurons for maintenance of brain 5-HT levels. Levels of 5-HT were determined by HPLC in dissected midbrain or forebrain tissue at the indicated ages. Control 5-HT levels were significantly increased in midbrain and forebrain at each of the indicated postnatal ages $(p<0.001)$. 5-HT levels in En $1 / 2^{5 H T C K O}$ midbrain were not significantly increased between 3 and 6 weeks of age $(p>0.05)$. 5 -HT levels in $E n 1 / 2^{5 H T C K O}$ forebrain tissue were not significantly increased between $\mathrm{P} 0$ and 3 weeks $(p>0.05) . n=14$ mice per genotype per age. Data are presented in mean \pm SEM; two-way ANOVA with Bonferroni's post hoc tests. ${ }^{* * *} p<0.001$.

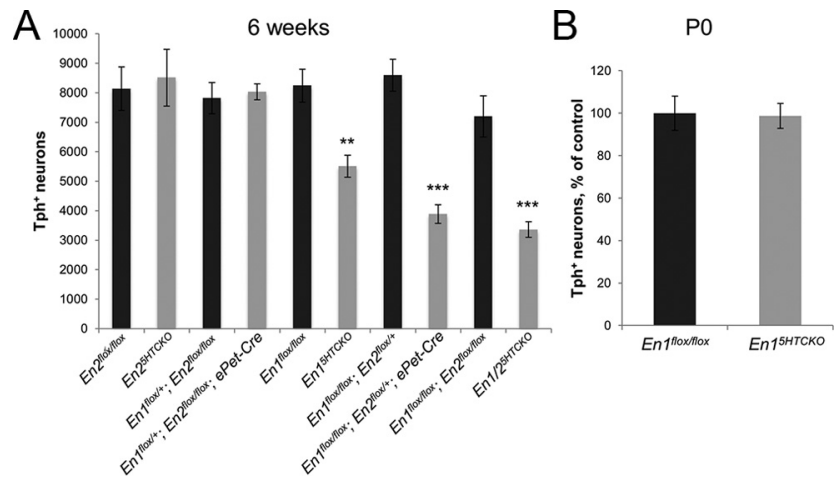

Figure 8. En1 is the predominant functional En paralog for maintenance of 5-HT neuron identity. $\boldsymbol{A}$, The number of $\mathrm{Tph}^{+}$neurons at 6 weeks of age in the DRN of indicated control floxed mice without $e P e t-C r e$ (black bars) or En-deficient conditional knock-out mice (gray bars) for each combination of floxed $E n 1$ and En2 alleles. The number of DRN Tph ${ }^{+}$neurons in $E n 1^{5 H T C K O}$ mice was significantly different from En $1 / 2^{5 H T C K O}$ and $E n 1^{f l o x} /$ flox $; E n 2^{f l o x /+} ; e P e t-C r e$ mice $(p<0.05)$. The number of DRN Tph ${ }^{+}$neurons were not significantly different between $E n 1 / 2^{\text {SHTCKO}}$ and $E n 1^{f l o x f f l o x} ; E n 2^{f l o x /+} ; e P e t-C r e$ mice $(p>0.05) . n=3-5$ mice per genotype; two-way ANOVA with Bonferroni's post hoc tests. $\boldsymbol{B}$, Relative numbers of $\mathrm{Tph}^{+}{ }^{+}$neurons in the $D R N$ of $E n 7^{\text {flox fllox }}$ controls and $E n 1^{5 H T C K O}$ mice at PO. $n=3$ mice per genotype; two-tailed $t$ test. Data are presented as mean \pm SEM. ${ }^{* *} p<0.01,{ }^{* * *} p<0.001$.

homeodomain proteins in early 5-HT neuron development ( $\mathrm{Si}$ mon et al., 2005). However, the use of constitutive targeting approaches precluded determination of intrinsic serotonergic roles, because it is well established that these factors perform critical functions in maintaining the mid-hindbrain organizer region (Liu and Joyner, 2001), from which Fgf8, an extrinsic determinant of rostral 5-HT neurons (Ye et al., 1998), is produced and secreted (Crossley et al., 1996). Here, we used conditional targeting approaches to investigate ongoing En1/2 function specifically in postmitotic 5-HT neurons without perturbing earlier functions in patterning or specification. We show that persistent En1/2 expression in postmitotic 5-HT neurons is required for the development of the DRN cytoarchitecture and the maintenance and survival of DRN 5-HT neurons. These unexpected roles in 5-HT neuron maturation, maintenance, and survival define an important stage of intrinsic En function in 5-HT neurons.

It is now evident that the En genes are expressed in the serotonergic lineage beginning at the progenitor stage and continuing into adulthood. Fate mapping using an En1-Cre knock-in allele
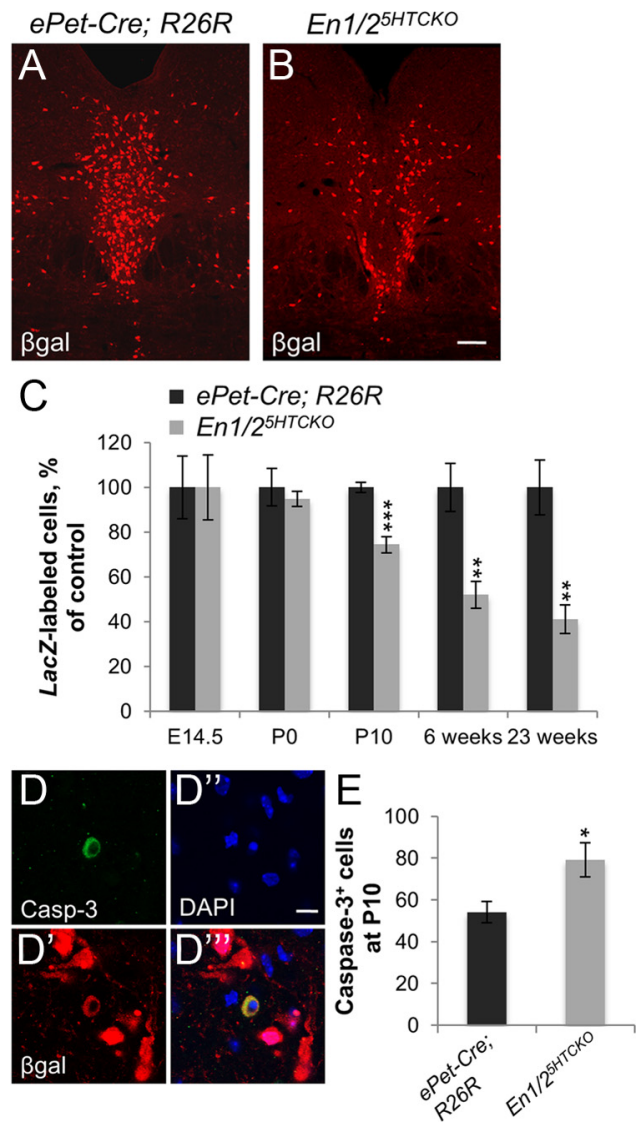

Figure 9. En is required for survival of postmitotic 5-HT neurons. $A, B$, Immunohistochemical detection of $\beta$-gal ${ }^{+}$DRN 5 -HT neurons in ePet-Cre; R26R control $(\boldsymbol{A})$ and En $1 / 2^{5 H T C K O}(\boldsymbol{B})$ mice on coronal sections at 6 weeks of age. $C$, Relative numbers of LacZ-marked DRN 5 -HT neurons in the rostral hindbrain at E14.5 or DRN at postnatal ages in control and En $1 / 2^{5 H T C K O}$ mice at the indicated embryonic stage or postnatal ages; $n=3-5$ mice per genotype per age. $\mathbf{D}-\mathbf{D}^{\prime \prime \prime}$, Coimmunostaining for cleaved caspase-3 (Casp-3), $\beta$-gal, and DAPI in the DRN of En1/2 $2^{\text {HHTCO }}$ mice at P10. $\boldsymbol{D}^{\prime \prime}$, Merge of $\boldsymbol{D}, \boldsymbol{D}^{\prime}$, and $\boldsymbol{D}^{\prime \prime}$. $\boldsymbol{E}$, Numbers of cleaved caspase- $3^{+} /\left.D A P\right|^{+}$cells in the DRN of ePet-Cre; R26R control and $E n 1 / 2^{5 H T K O}$ mice at $P 10 ; n=5$ mice per genotype. Data are presented as mean \pm SEM; two-tailed $t$ test. ${ }^{*} p<0.05,{ }^{* *} p<0.01,{ }^{* * *} p<0.001$. Scale bars: (in $\boldsymbol{B}) \boldsymbol{A}, \boldsymbol{B}, 100 \mu \mathrm{m}$; (in $\left.\boldsymbol{D}^{\prime \prime}\right) \boldsymbol{D}-\boldsymbol{D}^{\prime \prime \prime}, 10 \mu \mathrm{m}$.

provided evidence in support of En1 expression in rostral serotonergic progenitors within $\mathrm{rl}$ (Li and Joyner, 2001; Zervas et al., 2004), which give rise to all 5-HT neurons in the DRN and a subset of 5-HT neurons in the MRN and B9 cluster (Jensen et al., 2008). The present analysis corroborates our previous microarray evidence (Wylie et al., 2010) in support of En expression in rostral but not caudal postmitotic 5-HT neurons. In addition, our findings show that, although serotonergic En1 expression extends into adulthood, En2 expression is no longer detectable at E17.5. Because initial studies of En expression did not detect En1/2 in 5-HT neurons, it was concluded that En regulates 5-HT neuron development indirectly through their control of positional information emanating from the mid-hindbrain organizer (Simon et al., 2005). Although our expression studies do not refute this interpretation, they raise the possibility that En also play an intrinsic role in serotonergic progenitors. Distinguishing between these possibilities will require conditional targeting of En in serotonergic progenitors.

Conditional targeting of En paralogs in 5-HT neurons enabled the identification of a unique stage of En1/2 function separate from the earlier stage revealed in constitutive En1/2 null mice (Simon et al., 2005). Our findings indicate that continued En1/2 
function is required during 5 -HT neuron maturation to regulate cytoarchitectural maturation of the DRN and maintenance of serotonergic identity. Conditional loss of En1 and En2 led to maturation and maintenance defects in $\mathrm{r}$-derived 5-HT neurons but not in 5-HT neurons derived from more caudal regions. These findings are consistent with the restricted expression of En1 in $\mathrm{r} 1$ of the rostral hindbrain. Interestingly, we show that many LacZ-marked, En1/2-targeted 5-HT neuron cell bodies within the developing DRN failed to reach the midline and appeared to be stalled in an earlier embryonic configuration, reflecting completion of only their primary ventral migration through somal translocation away from the ventricular zone. Our findings do not preclude an intrinsic role for En in primary migration because the loss of En with our targeting approach may have occurred too late to detect disruption of this developmental step. The cytoarchitectural defects were not likely the result of altered patterns of serotonergic neurogenesis along the anterior-posterior axis because En was targeted after this developmental stage. Together, our findings suggest that loss of En disrupted subsequent secondary cell body migration during which the bilateral clusters of rostral 5-HT neurons fuse to form the midline structure of the DRN. These results, therefore, provide evidence in support of an active intrinsic regulatory program governing formation of the DRN. Targeting of Lmxlb and Gata-3, two other postmitotically expressed serotonergic transcriptional determinants, did not cause disruption of DRN cytoarchitecture (Zhao et al., 2006; Liu et al., 2010), and Pet-1 deficiency caused only modest lateralization of some DRN 5-HT neuron cell bodies (Krueger and Deneris, 2008). The mispositioning of 5-HT neuron cell bodies in the En1/2-deficient rostral hindbrain, therefore, reveals a unique function for En in the cytoarchitectural maturation of the DRN.

In additional contrast to loss of Pet- 1 and $L m \times 1 b$ (Zhao et al., 2006; Liu et al., 2010), conditional En1/2 deficiency did not affect serotonergic identity immediately after neurogenesis but caused a loss of identity in the perinatal period. Further analyses showed that 5-HT cell bodies in En1/2 ${ }^{5 H T C K O}$ mice were subsequently lost in the early postnatal period. A concomitant increase in the number of cleaved caspase- $3^{+}$cells in the mutant DRN suggests that continued En1/2 expression is required to prevent apoptosis of 5 -HT neurons. The loss of 5-HT neurons is not likely caused by 5-HT deficiency, because 5-HT-deficient neurons were not eliminated in the Pet-1 ${ }^{-/-}$DRN (Krueger and Deneris, 2008). Perhaps the mis-positioning of 5-HT neurons away from the midline renders them sensitive to limiting amounts of survival factors and hence vulnerable to cell death. Despite our estimated targeting efficiency of $85 \%$ and En expression in all DRN 5-HT neurons, we found that En1/2 deficiency affected the identity and survival of only 50-60\% of DRN 5-HT neurons through 23 weeks of age. In contrast, $\sim 90 \%$ of $5-\mathrm{HT}^{+}$neurons within the presumptive DRN were missing by E12 in constitutive $E n 1^{-/-} ; E n 2^{-/-}$mice (Simon et al., 2005). It is unclear why approximately one-third of En1/2-targeted 5-HT neurons were spared in En1/2 ${ }^{5 H T C K O}$ mice. Nevertheless, a common finding is that many 5-HT neurons exhibit resistance to phenotypic changes in serotonergic transcription factor null mutants (Briscoe et al., 1999; van Doorninck et al., 1999; Hendricks et al., 2003; Pattyn et al., 2004; Jacob et al., 2009). Interestingly, resistant 5 -HT neurons in the Pet-1 ${ }^{-1-}$ brain constitute a distinct functional subset of Pet- ${ }^{+}$neurons (Kiyasova et al., 2011). Although the 5-HT neurons that lose identity in the En1/2-deficient brain appear uniformly distributed throughout the DRN and, therefore, do not appear to be anatomically distinct, additional studies will be necessary to determine whether the En1/2 deficiency-resistant 5-HT neurons constitute a functional subclass. En also plays a critical, cellautonomous role in the survival of mesDA neurons because all of these neurons are missing in En1/2 homozygous null mice as a result of apoptosis at E14 (Albéri et al., 2004). In addition, a portion of SN and VTA DA neurons slowly degenerate and die postnatally in $E n 1^{+/-}$mice and $E n 1^{+/-} ; E n 2^{-/-}$mice (Sgadò et al., 2006; Sonnier et al., 2007). Interestingly, En-mediated DA neuroprotection appears to result from posttranscriptional cytoplasmic stimulation of mRNA translation of mitochondrial complex I proteins (Alvarez-Fischer et al., 2011). Although we detected abundant nuclear localization of En protein in 5-HT neurons, the findings in mesDA neurons raise the possibility that a similar posttranscriptional mechanism might be involved in the postnatal survival of 5-HT neurons.

The En allelic dosage requirements for postnatal 5-HT neuron identity and survival are notably different from those at early embryonic stages of 5-HT neuron development and in postnatal mesDA neuron development (Simon et al., 2001; Albéri et al., 2004). First, normal numbers of DRN 5-HT neurons were present in either En1 or En2 homozygous constitutive null (Simon et al., 2005) and En1 $1^{5 H T C K O}$ mice at P0. In addition, despite the complete loss of mesDA neurons by E14 in En1/2 homozygous null mice, normal numbers of mesDA neurons are present in En1 or En2 constitutive null mice at P0 (Simon et al., 2001; Albéri et al., 2004). Thus, En1 and En2 can fully compensate for one another at early stages of monoamingeric neuron development. In contrast, we found significantly fewer 5-HT neurons in young adult, conditionally targeted En1 mice $\left(E n 1^{5 H T C K O}\right)$ but normal numbers in $E n 2^{5 H T C K O}$ mice. However, the deficit in $E n 1^{5 H T C K O}$ mice was not as severe as that found in En1/2 $2^{5 H T C K O}$. These analyses therefore reveal a transient and modest contribution from En2 in rostral 5-HT neurons, which is essentially consistent with normal brain 5-HT levels in En $2^{-/-}$mice, except for a slight elevation of 5-HT in the cerebellum (Cheh et al., 2006). Second, a single En2 allele can partially compensate for constitutive loss of three En alleles in 5-HT (Simon et al., 2005) and mesDA neuron development (Simon et al., 2001). However, it cannot compensate for maintenance of 5-HT neuron identity in conditional mutants (Fig. 8A). Third, a single En1 allele is sufficient to maintain normal numbers of 5-HT neurons through 6 weeks of age. However, as described above, the presence of only a single functional En1 allele causes a slow postnatal degeneration of SN DA neurons. It is not clear, however, whether this is the result of deficient En activity in early development or during the postnatal period (Sgadò et al., 2006). Our findings therefore reveal a dominant cell-autonomous role for En1 in rostral 5-HT neurons. Although it has been shown that the En1 and En2 proteins are not functionally equivalent in all cellular contexts (Sillitoe et al., 2008), the dominant role of En1 in postmitotic 5-HT neurons is consistent with its persistent expression and the embryonic repression of En2 rather than functional differences between the two paralogs.

\section{References}

Albéri L, Sgadò P, Simon HH (2004) Engrailed genes are cell-autonomously required to prevent apoptosis in mesencephalic dopaminergic neurons. Development 131:3229-3236.

Alvarez-Fischer D, Fuchs J, Castagner F, Stettler O, Massiani-Beaudoin O, Moya KL, Bouillot C, Oertel WH, Lombès A, Faigle W, Joshi RL, Hartmann A, Prochiantz A (2011) Engrailed protects mouse midbrain dopaminergic neurons against mitochondrial complex I insults. Nat Neurosci 14:1260-1266.

Briscoe J, Sussel L, Serup P, Hartigan-O’Connor D, Jessell TM, Rubenstein JL, Ericson J (1999) Homeobox gene Nkx2.2 and specification of neuronal identity by graded Sonic Hedgehog signalling. Nature 398:622-627. 
Cheh MA, Millonig JH, Roselli LM, Ming X, Jacobsen E, Kamdar S, Wagner GC (2006) En2 knockout mice display neurobehavioral and neurochemical alterations relevant to autism spectrum disorder. Brain Res 1116:166-176.

Cheng Y, Sudarov A, Szulc KU, Sgaier SK, Stephen D, Turnbull DH, Joyner AL (2010) The Engrailed homeobox genes determine the different foliation patterns in the vermis and hemispheres of the mammalian cerebellum. Development 137:519-529.

Craven SE, Lim KC, Ye W, Engel JD, de Sauvage F, Rosenthal A (2004) Gata2 specifies serotonergic neurons downstream of sonic hedgehog. Development 131:1165-1173.

Crossley PH, Martinez S, Martin GR (1996) Midbrain development induced by FGF8 in the chick embryo. Nature 380:66-68.

Davis CA, Holmyard DP, Millen KJ, Joyner AL (1991) Examining pattern formation in mouse, chicken and frog embryos with an En-specific antiserum. Development 111:287-298.

Deneris ES (2011) Molecular genetics of mouse serotonin neurons across the lifespan. Neuroscience 197:17-27.

Deneris ES, Wyler SC (2012) Serotonergic transcriptional networks and potential importance to mental health. Nat Neurosci 15:519-527.

Ding YQ, Marklund U, Yuan W, Yin J, Wegman L, Ericson J, Deneris E, Johnson RL, Chen ZF (2003) Lmxlb is essential for the development of serotonergic neurons. Nat Neurosci 6:933-938.

Hawthorne AL, Wylie CJ, Landmesser LT, Deneris ES, Silver J (2010) Serotonergic neurons migrate radially through the neuroepithelium by dynamin-mediated somal translocation. J Neurosci 30:420-430.

Hendricks T, Francis N, Fyodorov D, Deneris ES (1999) The ETS domain factor Pet-1 is an early and precise marker of central 5-HT neurons and interacts with a conserved element in serotonergic genes. J Neurosci 19:10348-10356.

Hendricks TJ, Fyodorov DV, Wegman LJ, Lelutiu NB, Pehek EA, Yamamoto B, Silver J, Weeber EJ, Sweatt JD, Deneris ES (2003) Pet-1 ETS gene plays a critical role in 5-HT neuron development and is required for normal anxiety-like and aggressive behavior. Neuron 37:233-247.

Jacob J, Ferri AL, Milton C, Prin F, Pla P, Lin W, Gavalas A, Ang SL, Briscoe J (2007) Transcriptional repression coordinates the temporal switch from motor to serotonergic neurogenesis. Nat Neurosci 10:1433-1439.

Jacob J, Storm R, Castro DS, Milton C, Pla P, Guillemot F, Birchmeier C, Briscoe J (2009) Insml (IA-1) is an essential component of the regulatory network that specifies monoaminergic neuronal phenotypes in the vertebrate hindbrain. Development 136:2477-2485.

Jensen P, Farago AF, Awatramani RB, Scott MM, Deneris ES, Dymecki SM (2008) Redefining the serotonergic system by genetic lineage. Nat Neurosci 11:417-419.

Kiyasova V, Fernandez SP, Laine J, Stankovski L, Muzerelle A, Doly S, Gaspar P (2011) A genetically defined morphologically and functionally unique subset of 5-HT neurons in the mouse raphe nuclei. J Neurosci 31:2756-2768.

Krueger KC, Deneris ES (2008) Serotonergic transcription of human FEV reveals direct GATA factor interactions and fate of Pet-1-deficient serotonin neuron precursors. J Neurosci 28:12748-12758.

Kuemerle B, Zanjani H, Joyner A, Herrup K (1997) Pattern deformities and cell loss in Engrailed-2 mutant mice suggest two separate patterning events during cerebellar development. J Neurosci 17:7881-7889.

Levitt P, Moore RY (1978) Developmental organization of raphe serotonin neuron groups in the rat. Anat Embryol (Berl) 154:241-251.

Li JY, Joyner AL (2001) Otx2 and Gbx2 are required for refinement and not induction of mid-hindbrain gene expression. Development 128:4979-4991.

Li JY, Lao Z, Joyner AL (2002) Changing requirements for Gbx2 in development of the cerebellum and maintenance of the mid/hindbrain organizer. Neuron 36:31-43.

Lidov HG, Molliver ME (1982a) An immunohistochemical study of serotonin neuron development in the rat: ascending pathways and terminal fields. Brain Res Bull 8:389-430.

Lidov HG, Molliver ME (1982b) Immunohistochemical study of the development of serotonergic neurons in the rat CNS. Brain Res Bull 9:559-604.

Liu A, Joyner AL (2001) EN and GBX2 play essential roles downstream of FGF8 in patterning the mouse mid/hindbrain region. Development 128:181-191.

Liu C, Maejima T, Wyler SC, Casadesus G, Herlitze S, Deneris ES (2010) Pet-1 is required across different stages of life to regulate serotonergic function. Nat Neurosci 13:1190-1198.

Loomis CA, Harris E, Michaud J, Wurst W, Hanks M, Joyner AL (1996) The mouse Engrailed-1 gene and ventral limb patterning. Nature 382:360-363.

Lundell MJ, Chu-LaGraff Q, Doe CQ, Hirsh J (1996) The engrailed and huckebein genes are essential for development of serotonin neurons in the Drosophila CNS. Mol Cell Neurosci 7:46-61.

Millen KJ, Hui CC, Joyner AL (1995) A role for En-2 and other murine homologues of Drosophila segment polarity genes in regulating positional information in the developing cerebellum. Development 121:3935-3945.

Nicholson DW, Ali A, Thornberry NA, Vaillancourt JP, Ding CK, Gallant M, Gareau Y, Griffin PR, Labelle M, Lazebnik YA, Munday NA, Raju SM, Smulson ME, Yamin TT, Yu VL, Miller DK (1995) Identification and inhibition of the ICE/ CED-3 protease necessary for mammalian apoptosis. Nature 376:37-43.

Pattyn A, Simplicio N, van Doorninck JH, Goridis C, Guillemot F, Brunet JF (2004) Ascl1/Mash1 is required for the development of central serotonergic neurons. Nat Neurosci 7:589-595.

Pfaffl MW, Horgan GW, Dempfle L (2002) Relative expression software tool (REST) for group-wise comparison and statistical analysis of relative expression results in real-time PCR. Nucleic Acids Res 30:e36.

Scott MM, Krueger KC, Deneris ES (2005a) A differentially autoregulated Pet- 1 enhancer region is a critical target of the transcriptional cascade that governs serotonin neuron development. J Neurosci 25:2628-2636.

Scott MM, Wylie CJ, Lerch JK, Murphy R, Lobur K, Herlitze S, Jiang W, Conlon RA, Strowbridge BW, Deneris ES (2005b) A genetic approach to access serotonin neurons for in vivo and in vitro studies. Proc Natl Acad Sci U S A 102:16472-16477.

Sgadò P, Albéri L, Gherbassi D, Galasso SL, Ramakers GM, Alavian KN, Smidt MP, Dyck RH, Simon HH (2006) Slow progressive degeneration of nigral dopaminergic neurons in postnatal Engrailed mutant mice. Proc Natl Acad Sci U S A 103:15242-15247.

Sgaier SK, Lao Z, Villanueva MP, Berenshteyn F, Stephen D, Turnbull RK, Joyner AL (2007) Genetic subdivision of the tectum and cerebellum into functionally related regions based on differential sensitivity to engrailed proteins. Development 134:2325-2335.

Sillitoe RV, Stephen D, Lao Z, Joyner AL (2008) Engrailed homeobox genes determine the organization of Purkinje cell sagittal stripe gene expression in the adult cerebellum. J Neurosci 28:12150-12162.

Sillitoe RV, Vogel MW, Joyner AL (2010) Engrailed homeobox genes regulate establishment of the cerebellar afferent circuit map. J Neurosci 30:10015-10024.

Simon HH, Saueressig H, Wurst W, Goulding MD, O'Leary DD (2001) Fate of midbrain dopaminergic neurons controlled by the engrailed genes. J Neurosci 21:3126-3134.

Simon HH, Thuret S, Alberi L (2004) Midbrain dopaminergic neurons: control of their cell fate by the engrailed transcription factors. Cell Tissue Res 318:53-61.

Simon HH, Scholz C, O’Leary DD (2005) Engrailed genes control developmental fate of serotonergic and noradrenergic neurons in mid- and hindbrain in a gene dose-dependent manner. Mol Cell Neurosci 28:96-105.

Sonnier L, Le Pen G, Hartmann A, Bizot JC, Trovero F, Krebs MO, Prochiantz A (2007) Progressive loss of dopaminergic neurons in the ventral midbrain of adult mice heterozygote for Engrailed1. J Neurosci 27:1063-1071.

Soriano P (1999) Generalized lacZ expression with the ROSA26 Cre reporter strain. Nat Genet 21:70-71.

van Doorninck JH, van Der Wees J, Karis A, Goedknegt E, Engel JD, Coesmans M, Rutteman M, Grosveld F, De Zeeuw CI (1999) GATA-3 is involved in the development of serotonergic neurons in the caudal raphe nuclei. J Neurosci 19:RC12(1-8).

Vertes RP, Crane AM (1997) Distribution, quantification, and morphological characteristics of serotonin-immunoreactive cells of the supralemniscal nucleus (B9) and pontomesencephalic reticular formation in the rat. J Comp Neurol 378:411-424.

Wallace JA, Lauder JM (1983) Development of the serotonergic system in the rat embryo: an immunocytochemical study. Brain Res Bull 10:459-479.

Wylie CJ, Hendricks TJ, Zhang B, Wang L, Lu P, Leahy P, Fox S, Maeno H, Deneris ES (2010) Distinct transcriptomes define rostral and caudal serotonin neurons. J Neurosci 30:670-684.

Ye W, Shimamura K, Rubenstein JL, Hynes MA, Rosenthal A (1998) FGF and Shh signals control dopaminergic and serotonergic cell fate in the anterior neural plate. Cell 93:755-766.

Zervas M, Millet S, Ahn S, Joyner AL (2004) Cell behaviors and genetic lineages of the mesencephalon and rhombomere 1. Neuron 43:345-357.

Zhao ZQ, Scott M, Chiechio S, Wang JS, Renner KJ, Gereau RW 4th, Johnson RL, Deneris ES, Chen ZF (2006) Lmxlb is required for maintenance of central serotonergic neurons and mice lacking central serotonergic system exhibit normal locomotor activity. J Neurosci 26:12781-12788. 